\title{
Nadzor Suda Europske unije nad mjerama ograničavanja (sankcijama) nametnutim fizičkim odnosno pravnim osobama
}

\section{Stjepan Novak*}

\author{
https://doi.org/10.31297/hkju.19.4.7 \\ UDK $\quad 343.1: 342.722(4) E U$ \\ 341.645(4)EU:343.1 \\ Review scientific paper / pregledni znanstveni rad \\ Received / primljeno: $\quad$ 7. 5.2018. \\ Accepted / prihvaćeno: 22.11.2018.
}

Ovaj rad bavi se nadzorom Suda Europske unije nad primjenom mjera ograničavanja odnosno sankcija protiv pojedinih fizičkih odnosno pravnih osoba, i to kako nadzorom nad sankcijama Vijeća sigurnosti Ujedinjenih naroda koje su implementirane u pravni poredak Unije tako i nad autonomnim mjerama ograničavanja Unije. Taj se nadzor odnosi na zaštitu temeljnih prava osoba prema kojima se sankcije primjenjuju zbog povezanosti s terorizmom odnosno financiranjem terorizma, proliferacijom nuklearnog oružja odnosno provođenja nasilne represije nad civilnim stanovništvom. Proučavat će se, u pravilu, zaštita prava vlasništva s jedne i zaštita procesnih prava s druge strane. $U$ radu će se analizirati sadržaj tog nadzora Suda EU-a, ali i

* Dr. sc. Stjepan Novak, Ministarstvo unutarnjih poslova Republike Hrvatske, Zagreb, Hrvatska (Ministry of the Interior of the Republic of Croatia, Zagreb, Croatia, e-mail: stjepannovak@hotmail.com). Mišljenja i stavovi izraženi u radu autorova su osobna mišljenja i ne predstavljaju stav institucije u kojoj radi.

ORCID ID: 0000-0002-6600-4974. 
posljedice toga nadzora u smislu konkretne zaštite navedenih prava.

Ključne riječi: mjere ograničavanja, sankcije, Sud EU-a, zaštita temeljnih prava, pravo vlasništva, procesna prava

\section{Uvod}

Cilj rada je analizirati nadzor koji je Sud EU-a provodio nad mjerama ograničavanja, odnosno sankcijama nametnutim osobama ili entitetima povezanim s terorizmom, proliferacijom nuklearnog oružja odnosno provođenjem nasilne represije nad civilnim stanovništvom.

Oko definicije pojma sankcija u teoriji ne postoji suglasnost (Lapaš, 2004., str. 306; vidi npr. Anthony, 2002., str. 204, Canor, 1998., str. 138), dok je za pravo Europske unije karakterističniji pojam „mjere ograničavanja“. Čl. 215. Ugovora o funkcioniranju Europske unije (u daljnjem tekstu: UFEU) nosi naslov: Mjere ograničavanja te govori o „prekidu ili djelomičnom ili potpunom smanjenju gospodarskih i financijskih odnosa s jednom ili više trećih zemalja, kao i usvajanju takvih mjera protiv fizičkih ili pravnih osoba i skupina ili nedržavnih subjekata". ${ }^{1}$

Pojamom „mjera ograničavanja“ koristi se i hrvatsko zakonodavstvo, točnije Zakon o međunarodnim mjerama ograničavanja. ${ }^{2}$ Prema čl. 2/2. istog Zakona, mjere ograničavanja mogu biti: a) prekid diplomatskih odnosa, b) potpuni ili djelomični prekid gospodarskih odnosa, c) potpuna ili djelomična ograničenja uvoza, izvoza, provoza, pružanja usluga te prometnih, poštanskih i drugih komunikacija, d) embargo na oružje, e) ograničenja ulaska u zemlju, f) ograničenja raspolaganja imovinom i g) druge mjere u skladu s međunarodnim pravom.

Potrebno je naglasiti da je pojam „sankcije“ viši pojam u odnosu prema pojamu „mjera ograničavanja“; tako pojam mjera ograničavanja, kao što se vidi iz definicija UFEU-a ili hrvatskog Zakona o međunarodnim mjerama ograničavanja, ne obuhvaća sankcije upotrebom sile (Lapaš, 2004., str. 306) ili npr., rječnikom Povelje UN-a, operacije zračnih, pomorskih ili kopnenih snaga.

Međutim, kada govorimo o sankcijama, odnosno mjerama ograničavanja u smislu zamrzavanja imovine osoba odnosno entiteta povezanih $\mathrm{s}$

\footnotetext{
${ }^{1}$ V. u tom smislu Tzanakopoulos, 2015., str. 146.

${ }^{2}$ Zakon o međunarodnim mjerama ograničavanja (NN 139/08, 41/14).
} 
terorizmom te zabrane putovanja, tada se ti pojmovi, u pravnoj teoriji, upotrebljavaju kao sinonimi (Cardwell, 2015., str. 288; Misheva \& Duić, 2015., str. 22; Leenders, 2014., str 3; Portela, 2014., str. 4). Također, često se i u samim aktima institucija Europske unije ti pojmovi navode kao istoznačni. ${ }^{3} \mathrm{U}$ tom smislu ti će se pojmovi koristiti kao sinonimi, ovisno o kontekstu u kojem će se spominjati.

$\mathrm{Na}$ ovom mjestu možemo se kratko osvrnuti i na pravnu prirodu sankcija odnosno mjera ograničavanja o kojima će biti riječ u ovom radu. Pitanje pravne prirode sankcija Vijeća sigurnosti Ujedinjenih naroda (u daljnjem tekstu: VSUN) svodi se na pitanje je li, u konkretnom slučaju, riječ o građanskim odnosno administrativnim sankcijama ili kaznenim. To je važno jer o tome ovisi i stupanj zaštite procesnih prava koja treba jamčiti osobama odnosno entitetima na koje se sankcije odnose. U skladu s time, ovisno o tome o kojim je sankcijama riječ, moglo bi se tvrditi da je stupanj zaštite procesnih prava pojedinaca i entiteta uvrštenih na Listu unutar sustava sankcija VSUN-a na zadovoljavajućoj razini odnosno da nije na takvoj razini (Gutherie, 2004., str. 503). „Ponašanje“ zbog kojeg se sankcije primjenjuju uglavnom se svodi na financiranje odnosno pomaganje terorističkih djela. Još je rezolucija 1373 (2001.) zahtijevala od država da kriminaliziraju takvo ponašanje. Ipak, u mnogim državama takve sankcije nameću upravo izvršna ili upravna, dakle administrativna tijela. Također, narav samih sankcija unutar tog režima više je preventivne naravi, jer im je cilj onemogućiti financiranje terorista i terorističkih djela (Gutherie, 2004., str. 503).

Nadalje, svakako je moguće konstatirati da su te sankcije izrazito teške za dotične pojedince odnosno entitete jer ih stigmatiziraju, ali i privremeno onemogućavaju u raspolaganju vlastitim financijskim sredstvima. Ipak one, pogotovo kada govorimo o zamrzavanju imovine i drugim oblicima blokiranja pristupa tih entiteta vlastitoj imovini, nisu „kazne“, u kaznenopravnom smislu.

${ }^{3}$ Npr. Guidelines implementation and evaluation of restrictive measures (sanctions) in the framework of the EU Common Foreign and Security Policy, Council of The European Union 11205/12 od 15. 6. 2012.https://europeansanctions.files.wordpress.com/2013/03/ eu-guidelines-on-sanctions-2012.pdf.

Basic Principles of the Use of Restrictive measures (Sanctions), Council of The European Union 10198/1/04 od 9. 7. 2018. http://register.consilium.europa.eu/doc/ srv?l=EN\&f=ST\%2010198\%202004\%20REV\%201.

Restrictive measures (sanctions) in force, Regulations based on Article 215 TFEU and Decision adopted in framework of the Common Foreign and Security Policy, European Commission, http://eeas.europa.eu/cfsp/sanctions/docs/measures_en.pdf 
VSUN je u Rezoluciji 1735 (2006.) te u Rezoluciji 1989 (2011.) izrijekom ustvrdio da su mjere o kojima je riječ preventivne naravi, neovisne o kaznenim standardima utvrdenim u nacionalnim pravima (vidi Genser \& Barth, 2010., str. 39). ${ }^{4}$

U presudi predmeta Kadi II, Sud EU-a definirao je mjere zamrzavanja imovine kao privremenu mjeru opreza, ${ }^{5}$ a na isti zaključak nailazi se i u drugim presudama Suda EU-a. ${ }^{6}$ Opći sud u presudi Kadi III ponovo je otvorio to pitanje, ${ }^{7}$ a nešto drugačije mišljenje imali su nezavisni odvjetnik Bot i Sud u presudi Kadi IV.

Nezavisni odvjetnik Bot zaključio je da je Opći sud bio u zabludi kad je doveo u pitanje preventivnu prirodu mjera zamrzavanja imovine. ${ }^{8} \mathrm{U}$ tom smislu možemo istaknuti i zaključak Suda u predmetu Kadi IV, prema kojem, usprkos njihovoj preventivnoj naravi, te restriktivne mjere imaju negativan utjecaj na slobode i prava osoba prema kojima se primjenjuju, uz znatno narušavanje njihova profesionalnog i obiteljskog života. Taj negativni utjecaj postoji zbog ograničenja korištenja njihovim pravom vlasništva i zbog trajanja primjene tih mjera, kao i zbog javne sramote koju prouzročavaju tim osobama. ${ }^{9}$

${ }^{4}$ Rezolucija 1735 (2006.), preambula; Rezolucija 1989 (2011.), preambula. Third Report of the Analytical Support and Sanctions Monitoring Team Appointed pursuantto Resolution 1526 (2004) concerning Al-Kaida and the taliban and Association Individuals and Entities, paras 41-42, U.N. Doc. S/2005/572 (9 September 2005).

${ }^{5}$ Presuda Suda Europske unije Yassin Abdullab Kadi i Al Barakaat International Foundation protiv Vijeća Europske unije i Komisije Europskih zajednica, spojeni predmeti C-402/05 P i C-415/05 ECLI:EU:C:2008:461, 3. 9. 2008., (dalje u tekstu Kadi II), para 358.

${ }^{6}$ Presuda Suda Europske unije Adib Mayaleb protiv Vijeća Europske unije, spojeni predmeti T307/12 i T408/13 ECLI:EU:T:2014:926. 5. 11. 2014., (dalje: Mayelab), para 175. Vidi i presud Suda Europske unije, Organisation des Modjahedines du people d'Iran protiv Vijeća Europske unije, T-228/02 ECLI:EU:T:2006:384, 12. 12. 2006. (dalje u tekstu OMPI I), para 71., presudu Suda Europske unije Stichting Al-Aqsa i Nizozemska Kraljevina protiv Vijeća Europske unije, C-539/10 P i 550/10 P, ECLI:EU:C:2012:711, 15. 11. 2012. (dalje: Al-Aqsa III), para 120., presudu Suda Europske unije Stichting Al-Aqsa protiv Vijeća Europske unije, T-348/07, ECLI:EU:T:2010:373, 9. 9. 2010. (dalje: Al-Aqsa II), para 168., presudu Suda Europske unije Jose Maria Sison protiv Vijeća Europske unije, T-47/03 DEP, ECLI:EU:T:2007:207, 11. 7. 2007. (dalje: Sison II), para 101.

${ }^{7}$ Presuda Suda Europske unije Yassin Abdullab Kadi protiv Europske komisije, T-85/09, ECLI:EU:T:2010:418, 30. 9. 2010. (dalje u tekstu Kadi III), para 150.

${ }^{8}$ Mišljenje nezavisnog odvjetnika C584/10 P, C593/10 P and C595/10 P, ECLI:EU:C:2013:176, 19.3.2013. (dalje: Mišljenje Kadi IV), para 68.

${ }^{9}$ Presuda Suda Europske unije Europska komisija i dr. protiv Yassin Abdullab Kadi, spojeni predmeti C-584/10 P, C-593/10 P i C-595/10 P, ECLI:EU:C:2013:518, 18.7.2013. (dalje u tekstu Kadi IV), para 132. 
S tim u vezi možemo navesti Willisov zaključak da se neovisno o navedenoj karakterizaciji takvih sankcija, makar to bilo i od VSUN-a, pri njihovoj primjeni moraju poštovati procesna prava pojedinaca i entiteta protiv kojih su usmjerene, s obzirom na težinu posljedica koje one sa sobom nose (Willis, 2010., str. 25; vidi i Eckes, 2012., str. 39).

Dakle, bilo bi nezahvalno jednoznačno odrediti te sankcije kao mjere kaznenog ili upravnog karaktera. Riječ je o mjerama sui generis koje karakterizira njihova preventivna narav, nužna ograničenja procesnih prava s obzirom na efekt iznenađenja u njihovoj primjeni te teške posljedice njihove primjene.

Nametanje sankcija osobama odnosno entitetima zbog povezanosti s terorizmom, proliferacijom nuklearnog oružja odnosno zbog provođenja nasilne represije nad civilnim stanovništvom svakako znači i zadiranje u određena njihova prava. To su upravo ona prava koja je, kako je navedeno, i Sud EU-a branio u tolikoj mjeri da se suprotstavio i autoritetu Povelje $\mathrm{UN}-\mathrm{a}$, a njih proglasio temeljnim načelima Europske unije. to se odnosilo kako na slučajeve u kojima je bila riječ o sankcijama Ujedinjenih naroda koje su bile implementirane u sustav Europske unije tako i na slučajeve kada je riječ bila o autonomnim sankcijama.

Riječ je u prvom redu o pravu vlasništva dotičnih „objekata sankcija“, u smislu nemogućnosti raspolaganja imovinom u njihovu vlasništvu, s obzirom na to da se mjere zamrzavanja imovine sukobljavaju upravo $s$ tim pravom. Zatim, riječ je i o pravu na obavljanje gospodarske djelatnosti, pravu na osobni i obiteljski život te pravu na ugled.

S druge strane, u najvećoj mjeri bila je riječ o povredi postupovnih prava navedenih osoba odnosno entiteta, konkretno prava na obranu u širem smislu riječi, prava na saslušanje (uključujući i pravo na pristup sudu) i prava na učinkovito pravno sredstvo, kao i, u vrlo velikom broju slučajeva, obvezi obrazlaganja akata kojima se sankcije nameću. Dakle, radi se o onim pravima koja se u stranoj terminologiji nazivaju due process.

U tom smislu, u radu će se prvo prikazati način na koji, provodeći nadzor nad mjerama ograničavanja, Sud EU-a štiti pravo vlasništva. Nakon toga, analizirat će se način na koji je Sud EU-a, u provođenju tog nadzora, štitio procesna prava. U tu svrhu pratit će se razvoj prakse Suda EU-a analizom njegovih relevantnih presuda. Konačno, upozorit će se i na problem koji se takvom ulogom Suda EU-a javlja na međunarodnopravnom planu s obzirom na situaciju u kojoj bi se mogle naći države članice Europske unije (sve članice i članice UN-a) ako Sud EU-a poništi odluku o primjeni sankcija VSUN-a. 


\section{Zaštita prava vlasništva}

Mjere ograničavanja odnosno sankcije zamrzavanja imovine osoba odnosno entiteta, neovisno o tome jesu li povezani s terorizmom, proliferacijom nuklearnog oružja ili provođenjem nasilne represije nad civilnim stanovništvom, po prirodi stvari dovode do ograničenja prava vlasništva tih osoba odnosno entiteta. Sukladno tome, kada Sud EU-a provodi nadzor nad primjenom takvih mjera odnosno sankcija, provjerava, između ostalog, i je li prilikom njihove primjene došlo do neprimjerenih ili prekomjernih ograničenja tog prava.

Jedan od poznatijih slučajeva koji je u tom kontekstu moguće istaknuti jest predmet Bosphorus, s već opisanim činjeničnim stanjem. Kako je navedeno, turski avioprijevoznik pobijao je odluku irskog ministarstva prometa koje je zadržalo jedan njegov avion u Dublinu slijedeći odredbe Uredbe 990/93. ${ }^{10}$ Ta je uredba predviđala pljenidbu aviona u većinskom vlasništvu osoba iz Savezne Republike Jugoslavije. Bosphorus nije bio vlasnik tog aviona, već ga je iznajmio od jugoslavenskog JAT-a te se pozivao na povredu svoga prava na posjed kao i prava bavljenja ekonomskom aktivnošću. Sud je taj argument odbio, istaknuvši da navedena prava nisu apsolutna te da ih se može podčiniti restrikcijama opravdanim općim interesima koje slijedi Europska zajednica (Puissochet, 1997., str. 1574; v. Crnić-Grotić \& Sgardelli Car, 2010., str. 990). ${ }^{11}$ Nakon toga, konstatirao je da svaka mjera koja nameće sankcije ima, po definiciji, posljedice koje utječu na pravo vlasništva, uzrokujući štetu osobama koje nisu ni na koji način odgovorne za situaciju koja je dovela do usvajanja sankcija. Također, zaključio je i da je za međunarodnu zajednicu važnost cilja koji se konkretnom mjerom, odnosno uredbom želi postići ${ }^{12}$ takva da opravdava negativne posljedice određenim sudionicima na tržištu (Bosphorus, para 22., 23. i 26.).

U predmetu Al Asad ${ }^{13}$ sestra sirijskog predsjednika Asada podnijela je tužbe radi poništenja sankcija nametnutih aktualnom sirijskom režimu, u

\footnotetext{
${ }^{10}$ Council Regulation (EEC) No 990/93 of 26 April 1993 concerning trade between the European Economic Community and the Federal Republic of Yugoslavia (Serbia and Montenegro).

${ }^{11}$ Presuda Suda Europske unije Bosphorus Hava Yollari Turizm ve Ticaret AS protiv Minister for Transport Energy and Communications i dr., zahtjev za prethodnu odluku: Supreme Court-Irska C-84/95, ECLI:EU:C:1996:312, 30. 7. 1996., (dalje: Bosphorus), para 21.

12 Riječ je bila o zaustavljanju masivnog kršenja ljudskih prava i međunarodnog humanitarnog prava na području Bosne i Hercegovine.

13 Presuda od 12. 3. 2014. Bušra alAsad protiv Vijeća Europske unije T-202/12 ECLI:EU:T:2014:113. (dalje:: Al Asad).
} 
dijelu u kojem se odnose na nju, s obzirom na njezinu povezanost s tim režimom. Tužiteljica je tvrdila da joj je, između ostalog, povrijeđeno i pravo vlasništva, koje je zaštićeno i člankom 17. Povelje o temeljnim pravima. ${ }^{14}$ Opći sud, pozvavši se na predmete Bospshorus i Al-Aqsa III, podsjetio je da to pravo ne uživa apsolutnu zaštitu, nego da ga se mora uzeti ovisno o njegovoj funkciji u društvu, s čim je u vezi moguće uvesti ograničenja tog prava uz ispunjenje dvaju uvjeta. Prvo, ta ograničenja moraju odgovarati ciljevima općeg interesa postavljenim od Unije i, drugo, s obzirom na postavljeni cilj, ona ne smiju predstavljati pretjeran i nepodnošljiv zahvat koji bi povrijedio samu bit prava vlasništva. Riječ je, dakle, ponovo bila o načelu proporcionalnosti (Al-Aqsa III, para 113. i 114.). Nakon provedenog testa, ${ }^{15}$ i s obzirom na cilj osporavanih mjera i njihovu važnost za međunarodnu zajednicu, Opći sud je odlučio da u konkretnom slučaju njezina prava nisu neproporcionalno ograničena te je njezina tužba odbijena.

Zanimljiv je i slučaj Möllendorf ${ }^{16}$ (Eeckhout, 2011., str. 537-539). Riječ je bila o slučaju iz Njemačke koji se odnosio na kupoprodaju zemljišta u Njemačkoj, s time da je jedan od trojice kupaca bio stavljen na popis iz Uredbe 881/2002. Kupoprodajna cijena bila je plaćena, ali još uvijek nije bila provedena konačna „registracija“ u zemljišnim knjigama. Nadležno zemljišnoknjižno tijelo odbijalo je provesti registraciju zato što je dotični kupac na navedenom popisu, s čim se u vezi Viši regionalni sud obratio Sudu EU-a putem prethodnog pitanja. Sud se prvo bavio pitanjem bi li konačnom „registracijom“ prijenosa vlasništva u konkretnom slučaju bili ispunjeni uvjeti iz čl. 2/3 Uredbe, prema kojima gospodarska sredstva ne smiju biti, izravno ili neizravno, učinjena dostupnim označenim osobama te je utvrdio da je odgovor na ovo pitanje pozitivan (Möllendorf, para 45.60.). Nakon toga, Sud EU-a bavio se pitanjem utječe li na primjenu sankcija o kojima je riječ činjenica da je sama transakcija provedena prije stav-

14 „Svatko ima pravo na vlasništvo nad svojom, na zakonit način stečenom imovinom, koristiti je, njome raspolagati i ostaviti je u nasljedstvo. Imovina nikome ne može biti oduzeta, osim u slučaju zaštite javnog interesa ili u slučajevima i pod uvjetima koje propisuje zakon, ako se pravodobno isplati odšteta za njezin gubitak. Korištenje imovinom može biti regulirano zakonom u mjeri u kojoj to zahtijeva opći interes."

15 U para 117. zaključeno je da se, što se tiče nužnosti mjera, može ustvrditi da alternativne i manje otegotne mjere, poput sustava prethodnog dopuštenja ili naknadne obveze obrazlaganja svrhe u koju se koriste isplaćena sredstva, ne omogućuju učinkovito postizanje zadanog cilja - pritiska na podupiratelje sirijskog režima koji ugnjetava civilno stanovništvo - osobito imajući u vidu mogućnost zaobilaženja nametnutih ograničenja.

16 Presuda Suda Europske unije Gerda Möllendorf $i$ Christiane Möllendorf-Niebuus, C-117/06, ECLI:EU:C:2007:596, 11. 10. 2007., (dalje: Möllendorf). 
ljanja dotične osobe na popis te na isto odgovorio negativno, pozivajući se na potreban momentalni učinak Uredbe (Möllendorf, para 61.-67.). Što se tiče pitanja eventualnog povrata plaćene cijene, sukladno iznimkama od čl. 2. Uredbe, propisanih čl. 2a/4b Uredbe, ${ }^{17}$ Sud EU-a utvrdio je da takvo pitanje treba rješavati prema konkretnom nacionalnom pravu (Möllendorf, para 68.-73.). Konačno, sličan je odgovor dao i o pitanju navodne povrede prava vlasništva, ne osoba kojima su nametnute sankcije, već ostalim uključenim u dotični pravni posao, odnosno predstavlja li, u konkretnom slučaju, obveza povrata iznosa kupoprodajne cijene od prodavatelja neproporcionalnu povredu njihova prava vlasništva. Dakle, prema mišljenju Suda, to je pitanje nacionalnog prava. Pritom, Sud je naglasio važnost zahtjeva koji proizlaze iz prava vlasništva unutar pravnog poretka Zajednice (Möllendorf, para 74.-78.; Murphy, 2011., str. 248; v. Cousins, 2008., str. 408).

Spomenimo i još jedan predmet u kojem je Sud EU-a bio nešto blaži u svom pristupu (Eeckhout, 2011., str. 540) prema pojedincima pogođenim sankcijama, ali, slikovito govoreći, stroži prema samom sustavu sankcija, odnosno Uredbi. Riječ je o predmetu M. $i$ ostali. ${ }^{18}$ Nadležno tijelo Ujedinjenog Kraljevstva tumačilo je tekst Uredbe 881/2002 tako da se njome propisane sankcije zamrzavanja fondova odnose i na određena socijalna primanja supružnika Uredbom označenih osoba, povodom čega je nadležni nacionalni sud postavio prethodno pitanje Sudu EU-a s tim u vezi. Sud EU-a je zaključio da je njezin cilj spriječiti označene osobe da imaju na raspolaganju ikakva financijska ili gospodarska sredstva kako bi se spriječilo financiranje terorističkih aktivnosti. Nadalje, zaključio je da je njezina svrha borba protiv međunarodnog terorizma, i to posebice tako da mu se učine nedostupnim financijski resursi, zamrzavanjem imovine osoba ili entiteta za koje se sumnja da su uključeni u aktivnosti povezane s terorizmom. Dakle, mjera zamrzavanja ekonomskih sredstava odnosi se samo na ona sredstva koja se mogu iskoristiti za podupiranje terorističkih aktivnosti. Kako je naveo Sud EU-a, navedeno nadležno tijelo Ujedinjenog Kraljevstva nije svoje tumačenje temeljilo ni na kakvoj opasnosti da bi supružnici označenih osoba mogli dobivena sredstva, u obliku socijalnih primanja, preusmjeriti prema potpomaganju terorističkih aktivnosti, to više što su, prema utvrđenju Suda EU-a, ta primanja utvrđena na razini

${ }^{17}$ Iznimke su uvedene Uredbom 561/2003.

18 Presuda Suda Europske unije, The Queen, na zahtjev M. i dr. protiv Her Majesty's Treasury, Zahtjev za prethodnu odluku: House of Lords - Ujedinjenog Kraljevstva, C-340/08, ECLI:EU:C:2010:23229. 4. 2010., (dalje: M. i ostali). 
koja je potrebna za pokrivanje osnovnih potreba osoba o kojima je riječ. Sukladno svemu navedenom, a posebno uzimajući u obzir načelo pravne sigurnosti, Sud EU-a je zaključio da se osporavana Uredba ne odnosi na takva socijalna primanja (M. i ostali, para 52.-74.; Eeckhout, 2011., str. 540; Murphy, 2011., str. 299).

U ovom kontekstu potrebno je osvrnuti se i na predmet Kadi. U predmetu Kadi I gospodin Kadi iz Saudijske Arabije i Al Barakaat, međunarodna zaklada, podnijeli su tužbu za poništenje Uredbe 881/2002 kojom im se nameću mjere ograničavanja, tvrdeći da im je, između ostalog, povrijeđeno pravo vlasništva i, sukladno tome, načelo proporcionalnosti. ${ }^{19}$ Opći sud naglasio je važnost cilja koji se osporavanom mjerom, dakle zamrzavanjem fondova tužitelja, želi postići te konstatirao da se tom mjerom „želi postići cilj od fundamentalnog javnog interesa za međunarodnu zajednicu“" (Kadi I, para 247.). Nadalje, naglasio je i da je, za razliku od konfiskacije, ovdje riječ o privremenim mjerama opreza, koje „ne utječu na samu srž prava vlasništva tužitelja" (Kadi I, para 248.). Također, istaknuo je i da je mjera o kojoj je riječ podložna periodičnim nadzorima te da tužitelji mogu osporavati mjeru pred Odborom $1267,{ }^{20}$ putem svojih država, odnosno država čiji su državljani ili na čijem području imaju prebivalište. Uzevši sve navedeno u obzir, Opći sud je zaključio da se mjera zamrzavanja fondova pojedinaca odnosno entiteta za koje se sumnja da su povezani s počiniteljima terorističkih akata odnosno da u njima sudjeluju, potpomažu ih ili ih financiraju ne može smatrati arbitrarnim, neprikladnim i neproporcionalnim kršenjem fundamentalnih prava tih osoba. $S$ tim u vezi odbio je tvrdnju da tužiteljima nije poštovano pravo vlasništva (Kadi I, para 249.-251.).

Sud je u drugom stupnju naveo kako je prema ustaljenoj sudskoj praksi pravo vlasništva jedno od općih načela prava Zajednice koje, međutim, nije apsolutno, nego se mora promatrati u vezi sa svojim funkcijama u za-

19 Presuda Suda Europske unije, Yassin Adullab Kadi protiv Vijeća Europske unije i Komisije Europskih zajednica, T-315/01, ECLI:EU:T:2005:332, 21. 9. 2005. (dalje u tekstu Kadi I)., para 234 .

${ }^{20}$ Rezolucijom 1267 (1999) osnovan je Odbor sastavljen od članica VSUN-a. Jedan od glavnih zadataka tog Odbora bio je utvrđivanje fondova i financijskih izvora povezanih s talibanima, njihovim ili s njima povezanim organizacijama, koje, potom, sve države trebaju zamrznuti. U tom smislu određuje mjere zamrzavanja imovine, ali i zabrane putovanja (tzv. travel ban), koje se sastoje u obvezi svake države da ne dopuste polijetanje s njihova teritorija ili slijetanje na njega zrakoplova u vlasništvu ili na bilo koji način povezanih s talibanima. Istom je Rezolucijom uspostavljena i posebna Lista pojedinaca ili grupa na ovaj način povezanih s terorizmom. 
jednici. Sukladno tome, ostvarenje prava vlasništva može biti ograničeno, pod pretpostavkom da ta ograničenja u biti odgovaraju ciljevima javnog interesa koji Zajednica želi ostvariti i ne predstavljaju, u vezi sa svojim ciljem, „nerazmjernu i nepodnošljivu smetnju“ (Kadi II, para 355.).

Nadalje, Sud je smatrao da treba ispitati dovodi li mjera zamrzavanja propisana spornom uredbom do nerazmjerne i nepodnošljive smetnje umanjenjem same biti temeljnog prava na poštovanje vlasništva. Nakon toga je zaključio da se mjera zamrzavanja sastoji od privremene mjere opreza koja ne treba lišiti te osobe njihova vlasništva, međutim koja nedvojbeno sadržava ograničenje ostvarivanja prava vlasništva tužitelja koje, s obzirom na njegovu trajnost, treba smatrati značajnim. Također, ustvrdio je da mora postojati razumna veza proporcionalnosti između upotrijebljenih sredstava i cilja koji se želi ostvariti, odnosno da Sud mora odrediti je li postavljena poštena ravnoteža između potreba javnog interesa i interesa pojedinaca pogođenih sankcijama. U tom smislu, Sud je ponovio svoja prijašnja utvrđenja da važnost ciljeva akta Zajednice može biti takva da opravdava negativne posljedice, čak i stvarne prirode, za određene pojedince, uključujući i one koji ni na koji način nisu odgovorni za situaciju koja je dovela do usvajanja mjera o kojima je riječ. U konkretnom slučaju, mjere propisane u spornoj uredbi doprinose implementaciji, na razini Zajednice, restriktivnih mjera o kojima odlučuje VSUN protiv Osame bin Ladena, članova organizacije Al-Kaide i talibana te drugih pojedinaca, grupa, poduzeća i subjekata koji su povezani s njima (Kadi II, para 356.-360.).

Prema nahođenju Suda, s obzirom na cilj općeg interesa međunarodne zajednice, a to je borba protiv prijetnji međunarodnom miru i sigurnosti zbog terorizma, mjere zamrzavanja sredstava, financijskih faktora i ostalih ekonomskih izvora osoba koje VSUN ili Odbor 1267 smatraju povezanim s Osamom bin Ladenom, članovima organizacije Al-Kaida i talibanima ne mogu se same po sebi smatrati neprimjerenima ili neproporcionalnima.

Sukladno svemu navedenom, Sud je zaključio da konkretna ograničenja prava vlasništva prema tužiteljima, u načelu, mogu biti opravdana. Međutim, Sud je uzeo u obzir procesne nedostatke u postupku usvajanja same uredbe. Zaključio je da je sporna Uredba, u mjeri u kojoj se odnosi na g. Kadija, usvojena bez pružanja ikakve garancije koja mu omogućava da postavi svoj predmet pred nadležna tijela, u situaciji u kojoj ograničenja njegova prava vlasništva treba smatrati značajnima, uzimajući u obzir opću primjenu i stvarne posljedice zamrzavanja njegovih sredstava. S obzirom na to, Sud je zaključio da, u konkretnom slučaju, nametanje restriktivnih mjera predstavlja neopravdano ograničenje njegova prava vlasništva (Kadi 
II, para 361.-370.). Isto je bilo i u presudama Othman, ${ }^{21}$ Al Faqih ${ }^{22}$ i Ayadi II. ${ }^{23}$

Takav način razmišljanja, kad govorimo o povredi prava vlasništva, zadržan je i u predmetima Kadi III (vidi para 192.-195.) i Kadi IV (vidi para 138.).

Kao što je navedeno, osim prava vlasništva, u ovom je kontekstu dolazilo i do ograničavanja nekih drugih prava. U tom kontekstu možemo izdvojiti i pravo obavljanja gospodarske djelatnosti. U presudi Ayadi I, donesenoj dvije godine prije presude Kadi II, riječ je bila o državljaninu Tunisa koji je prebivao na području Irske te prema kojem su primijenjene mjere ograničavanja implementirane Uredbom 881/2002, protiv kojih je podigao tužbu. ${ }^{24}$

Opći sud je konstatirao da primjena tih mjera ograničavanja nametnutih g. Ayadiju nije suprotna temeljnim ljudskim pravima koja ulaze u domenu ius cogens, s obzirom na njezin cilj, a to je borba protiv prijetnji međunarodnom miru i sigurnosti. Također, ocijenio je da mu primjena tih sankcija ne onemogućava vođenje uobičajenog, štoviše zadovoljavajućeg svakodnevnog života, kao ni, u teoriji, bavljenje poslovnim aktivnostima. Ograničenja koja su sastavni dio sankcija o kojima je riječ, prema zaključku Općeg suda, odnose se na raspolaganje prihodima od tih aktivnosti, a ne na samo njihovo obavljanje. U tom smislu, taj je Sud zaključio da je izdavanje dozvole za obavljanje djelatnosti taksi-prijevoznika osobi koja je podvrgnuta ovakvim sankcijama, kao i njezino unajmljivanje automobila za tu svrhu, moguće i dopustivo u smislu svojevrsnih odstupanja od primjena sankcija zamrzavanja imovine, uz napomenu da će najbolju odluku o tome donijeti nacionalna razina (Ayadi I, para 132.; v. Heliskoski, 2007., str.1151).

Zaključno, kada je riječ o zaštiti prava vlasništva, Sud EU-a dopuštao je mogućnost ograničavanja tog prava uz ispunjenje dvaju uvjeta: ograniče-

${ }^{21}$ Presuda Suda Europske unije Omar Mohammed Othman protiv Vijeća Europske unije $i$ Komisije Europskih zajednica, T-318/01, ECLI:EU:T:2009:187, 11. 6. 2009. (dalje: Othman).

22 Presuda Suda Europske unije Al-Bashir Mohammed Al-Faqib $i$ drugi protiv Vijeća Europse unije T-135/06 do T-138/06, ECLI:EU:T:2010:412, 29. 9. 2010.

${ }^{23}$ Presuda Suda Europske unije Faraj Hassan protiv Vijeća Europske unije i Komisije i Chafiq Ayadi protiv Vijeća, C-399/06 i 403/06, ECLI:EU:C:2009:748. 3.12. 2009. (dalje: Ayadi II) para 91.-94.

${ }^{24}$ Presuda Suda Europske unije Chafiq Ayadi protiv Vijeća EU-a, T-253/02 ECLI:EU: T:2006:200, 12. 6. 2006. (dalje:: Ayadi I), para 1.-49. 
nja moraju odgovarati ciljevima javnog interesa koji Europska unija želi ostvariti te ne smiju biti neproporcionalna tim istim ciljevima.

U sljedećem poglavlju prikazat će se, općenito, koja je procesna prava Sud EU-a štitio, zatim kako je to radio kada je bila riječ o fizičkim odnosno pravnim osobama te, konačno, kako je ta prava štitio osobama odnosno entitetima prema kojima su se mjere ograničavanja odnosno sankcije primjenjivale.

\section{Zaštita procesnih prava}

Kada govorimo o procesnim pravima, za koja su pojedinci odnosno entiteti pogođeni mjerama ograničavanja odnosno sankcijama tvrdili da su im povrijeđena, moguće je govoriti o nekoliko takvih prava, odnosno o nekoliko skupina takvih prava. U tom smislu možemo govoriti o pravu na saslušanje, pravu na učinkovito pravno sredstvo, pravu na učinkovitu pravnu zaštitu te pravu na obaviještenost, odnosno o pravu na obranu u širem smislu riječi. Ta su prava povezana i čine cjelinu te ih je Sud EU-a na takav način i interpretirao, odnosno ocjenjivao razinu njihove realizacije u konkretnim slučajevima.

Osim toga, Sud EU-a posebnu je pažnju posvećivao i sadržaju, odnosno kvaliteti obrazloženja odluka na temelju kojih su se određivale i primjenjivale mjere ograničavanja, sukladno čl. 296/2 UFEU-a, ${ }^{25} \mathrm{~s}$ obzirom na to da je to preduvjet za realizaciju prava na obranu (Hollenberg, 2015., str. 53; vidi i Kadi II, para 349.).

Zaštitu tih procesnih prava Sud EU-a primjenjivao je ne samo kada je bila riječ o osobama konkretno povezanim s terorizmom ili vladajućim režimima pojedinih država prema kojima su se mjere ograničavanja primjenjivale već i o članovima njihovih obitelji. (Tay Za, M. i ostali, Al-Asad itd.). Ista, slikovito rečeno, širina u primjeni zaštite vidi se i kod slučajeva koji su se odnosili na pravne osobe, odnosno organizacije. Tako je, primjerice, i u predmetu PKK II, u kojem je riječ bila o organizaciji koja je službeno prestala postojati, Sud EU-a zaključio da, s obzirom na to da je PKK „zadržao postojanje u dovoljnoj mjeri" da bude podvrgnut mjerama ograničavanja iz osporavane odluke, donesene također, nakon dana njegova navodnog

25 „U pravnim se aktima navode razlozi na kojima se akti temelje i u njima se upućuje na sve prijedloge, inicijative, preporuke, zahtjeve ili mišljenja koja su potrebna na temelju Ugovorâ." 
prestanka, mora se uzeti i da je „zadržao postojanje u dovoljnoj mjeri“ da može osporavati tu odluku.

Također, možemo reći da je Sud EU-a svoj nadzor provodio i u vremenskom pa i prostornom aspektu (Cardwell, 2015., str. 300). ${ }^{26}$ „Vremenski aspekt" nadležnosti Suda EU-a u nadzoru nad primjenom mjera ograničavanja odnosi se na vremenski okvir u kojemu su nastale odluke kojima su se navedene mjere odredivale te koje su pojedinci, odnosno entiteti pogođeni tim mjerama pobijali. U tom smislu, Sud EU-a često je ocjenjivao postojanje pravnog interesa tužitelja s obzirom na činjenicu da su odluke kojima su im mjere ograničavanja nametnute naknadno stavljene izvan snage.

Nadležnost u vremenskom aspektu do izražaja je dolazila, primjerice, u predmetima Abdulrabim II ili Ayadi III. Tako je Sud EU-a ocjenjivao postojanje pravnog interesa tužitelja s obzirom na činjenicu da su odluke kojima su im mjere ograničavanja nametnute naknadno stavljene izvan snage. Kao što je navedeno, u predmetu Abdulrabim II g. Abdulrahim pobijao je rješenje Općeg suda kojim je odlučeno da nema više potrebe odlučivati o tužbi kojom se traži poništavanje Uredbe 881/2002, s obzirom na naknadno brisanje njegova imena s relevantnog popisa. Sud je u ovom slučaju ponovio da tužitelj zadržava interes za poništavanjem odluke ili radi povrata u prijašnje stanje ili kako bi potaknuo donositelja osporavanog akta da poduzme odgovarajuće promjene radi izbjegavanja rizika ponavljanja nezakonitosti u pogledu tog akta u budućnosti.

Također, naglasio je i da pitanje zadržava li tužitelj pravni interes o kojem je riječ treba procjenjivati s obzirom na specifične okolnosti slučaja, pogotovo s obzirom na posljedice navodne nezakonitosti akta o kojem je riječ i prirodu navodno nanesene štete. U presudi Ayadi III Sud EU-a utvrdio je da pravni interes g. Ayadija i dalje postoji, unatoč tome što je primjena mjera ograničavanja prema njemu prekinuta, odnosno što je njegovo ime brisano s relevantnog popisa, i to zato da bi Sud EU-a utvrdio da primjene mjera ograničavanja nikad nije niti trebalo biti. ${ }^{27}$

Što se tiče „prostornog aspekta“, on dolazi do izražaja, u presudi OPMI II, u kojoj je konstatirano da Zajedničko stajalište 2001/931 odnosno Uredba 2850/2001 ni na jednome mjestu ne uvjetuju usvajanje odluke o primjeni vanja.

26 Ovo je donekle posljedica i samog prostornog širenja dosega samih mjera ograniča-

27 Presuda Suda Europske unije Chafiq Ayadi protiv Europske komisije, C-183/12 P, ECLI:EU:C:2013:369, 6. 6. 2013. (Ayadi III), para 60.-63. 
mjere zamrzavanja imovine počinjenjem terorističkog djela na teritoriju Europske unije. ${ }^{28} \mathrm{~S}$ druge strane, u presudi LTTE, Sud EU-a utvrdio je kako je na Vijeću EU-a da prije usvajanja vlastite odluke na temelju odluke nacionalnog tijela treće države pažljivo provjeri osigurava li relevantno zakonodavstvo te države zaštitu prava na obranu i prava na sudsku zaštitu ekvivalentnu onoj koja se jamči na razini Unije. To širenje nadležnosti u prostornom aspektu postaje očito uzmemo li u obzir da je u konkretnom slučaju riječ bila o indijskim tijelima. ${ }^{29}$

Najopsežniji zahvati u kontekstu primjene nadležnosti Suda EU-a odnosi se na područje zaštite procesnih prava osoba odnosno entiteta o kojima je riječ. ${ }^{30}$ Tako je Sud EU-a posebno štitio pravo na saslušanje tih osoba odnosno entiteta, ali i njihovo pravo da budu odgovarajuće obaviješteni o razlozima zbog kojih se sankcije prema njima primjenjuju, i to neovisno o tome je li bila riječ o implementiranim mjerama ili o autonomnim.

Kada je u pitanju bilo pravo na saslušanje kod sankcija VSUN-a, Sud EU-a imao je u vidu „obvezne zahtjeve međunarodnog javnog poretka“ te konstatirao da se to pravo „treba prilagoditi stupnjevitim administrativnim postupcima predviđenim u ovakvom sustavu sankcija." (Kadi I, para 267.). Kao i kada je bila riječ o ostalim pravima obrane, tako je i za ovo tvrdio da se ono ponajprije ostvaruje na nacionalnoj razini. Isto tako, utvrdio je da je pravo na obranu, pogotovo pravo na saslušanje, u svim postupcima koji mogu dovesti do usvajanja mjera koje mogu negativno utjecati na određeni entitet fundamentalno načelo Europske unije. To pravo mora biti zajamčeno, makar i ne postoje pravila koja uređuju postupak o kojem je riječ. Ipak, naveo je i da ni mjerodavni akti o kojima je riječ ni opće načelo očuvanja prava na obranu ne znače i pravo na saslušanje na službenoj raspravi. ${ }^{31}$

Na realizaciji prava na saslušanje Sud EU-a inzistirao je i kad je bila riječ o autonomnim sankcijama. Pritom je razlikovao tzv. inicijalnu primjenu

${ }^{28}$ Presuda Suda Europske unije People's Mojahedin Organization of Iran protiv Vijeća Europske unije, T-256/07 ECLI:EU:T:2008:461, 23. 10. 2008. (dalje u tekstu OMPI II), para 144.-148.

${ }^{29}$ Presuda Suda Europske unije Liberation Tigers of Tamil Eelam (LTTE) protiv Vijeća Europske unije, spojeni predmeti T-208/11 i T-508/11, ECLI:EU:T:2014:885, 16. 10. 2014. (dalje: LTTE), para 136.-154.

${ }^{30}$ O kojim pravima je riječ vidi npr. presudu Suda Europske unije Abdulbasit Abdulrabim protiv Vijeća Europske unije i Europske komisije, T-127/09 RENV, ECLI:EU:T:2015:4, 14. 1. 2015. (dalje: Abdulrabim III).

${ }^{31}$ Presuda Suda Europske unije Bank Melli Iran protiv Vijeća Europske unije, T-35/10, ECLI:EU:T:2013:397, 6. 9. 2013. (Bank Melli Iran III), para 78.-80. i 86.-90. 
sankcija od naknadne, kada je stranci potrebno dati priliku da iznese svoja gledišta oko opravdanosti razloga za njegovo zadržavanje na listi (OMPI I, para 114.-120.; Eckes \& Mendes, 2011., str. 12). Sud EU-a se sadržajem tog prava detaljno bavio u navedenom predmetu OMPI I, ali i njegovim ograničenjima, i to s obzirom na: a) potrebu njihove efikasnosti kod inicijalnih odluka o njihovoj primjeni, b) načelo iskrene suradnje iz čl. 4 UFEU-a i c) razloge koji se tiču sigurnosti Europske unije i njezinih država članica ili vođenja njihovih međunarodnih odnosa.

Posebnu pažnju Sud EU-a posvetio je obvezi obrazlaganja odluka o mjerama ograničavanja sukladno čl. 296. UFEU-a. Tako je uvijek naglašavao da nadležno tijelo Unije mora poštovati navedenu obvezu, osobito u pogledu preciznosti i konkretnosti danih razloga (v. npr. Kadi IV), neovisno o tome radi li se o implementiranim ili autonomnim mjerama ograničavanja. Riječ je zapravo o zahtjevu da pravni akti koji određuju sankciju sadržavaju razloge na kojima se temelje, odnosno da jasno i nedvosmisleno pokazuju „način razmišljanja“ Vijeća EU-a kako bi osoba koje se to tiče mogla utvrditi razloge te kako bi sudstvo Unije moglo izvršiti svoju ovlast nadzora. Zapravo, obveza obrazlaganja akta koji pogađa neku osobu, a koja proizlazi iz načela poštovanja prava na obranu, ima dva cilja. Prvo, dati pojedincu dostatnu uputu o tome je li mjera osnovana ili sadržava li neku drugu pogrešku koja omogućuje osporavanje njezine valjanosti pred Sudom EU-a. Drugo, omogućiti Sudu EU-a da provede nadzor te mjere.

Isto tako, obrazloženje se mora u načelu priopćiti zainteresiranoj osobi istodobno s aktom koji na nju negativno utječe. Njegovo nepostojanje ne može se ispraviti činjenicom da je zainteresirana osoba za obrazloženje akta saznala poslije tijekom postupka. Obveza obrazlaganja još je važnija ako osoba o kojoj je riječ nema pravo na prethodno saslušanje. Stoga obrazloženje ne treba navesti samo pravnu osnovu mjere na koju se odnosi, već i specifične i konkretne razloge zbog kojih Vijeće EU-a smatra da na pojedinca treba primijeniti takvu mjeru. Ipak, obrazloženje mora biti prilagođeno prirodi predmetnog akta i kontekstu u kojem je usvojen. Zahtjev za obrazloženjem mora se ocjenjivati kroz okolnosti konkretnog slučaja, u prvom redu kroz sadržaj akta, prirodu istaknutih razloga te interes koji osobe kojima je akt upućen ili druge osobe na koje se on izravno ili osobno odnosi mogu imati da dobiju objašnjenja. Nije nužno da obrazloženje sadržava sve relevantne činjenične i pravne elemente. Naime, dostatnost obrazloženja mora se primjenjivati ne samo s obzirom na njegov tekst, već i na kontekst te skup pravnih pravila koja uređuju predmetnu materiju. Jednostavnije, akt koji pogađa neku osobu dovoljno je obrazložen ako je donesen u kontekstu poznatom toj osobi koji joj omogućuje da razumije 
doseg mjere koja se na nju odnosi. Štoviše, tim uvjetima može biti udovoljeno i u slučaju vrlo sažetog obrazloženja. ${ }^{32}$

Dakle, je li navedenoj obvezi udovoljeno, potrebno je ocjenjivati ne samo s obzirom na sadržaj mjere koja se aktom određuje već i s obzirom na njezin kontekst, kao i na skup svih propisa koji reguliraju materiju o kojoj je riječ. Sadržaj i doseg te obveze Sud EU-a razvijao je kroz vlastitu praksu. U tom smislu, opseg razloga dovoljnih za ispunjavanje obveze o kojoj je riječ ovisi i o tome je li i u kojoj mjeri dotičnoj osobi poznat kontekst u kojem se usvaja sporna mjera. ${ }^{33}$

Nadalje, Sud EU-a postavio je i pravilo da se obveza obrazlaganja, kada je riječ o inicijalnoj odluci, odnosi na utvrđivanje postojanja preciznih podataka ili materijala iz odgovarajuće dokumentacije koja pokazuje da je odluku u vezi s tim osobama odnosno entitetima donijelo nadležno tijelo. Nadležno tijelo je sudsko tijelo ili drugo odgovarajuće tijelo ako u relevantnom području sudska vlast nema ovlasti. Kroz vlastitu praksu Sud se tim pitanjem često bavio. Tako je konstatirao da s obzirom na to da odluka nadležnog nacionalnog tijela može biti pobijana unutar tog nacionalnog sustava, sama činjenica da se o njoj odlučuje na višem stupnju ne znači da je Vijeće EU-a ne smije uzimati kao odlučujući faktor prilikom donošenja svoje odluke (vidi OMPI II, para 146.). Isto tako, i u slučaju odustanka od istrage odnosno kaznenog progona, istu činjenicu Vijeće EU-a mora uzeti u obzir (Sison II, para 116.; v. Eckes, 2012., str. 9).

U svakom slučaju sustav uspostavljen Uredbom 2580/2001 usvajanje odluke Vijeća EU-a o zamrzavanju imovine uvjetuje dvama faktorima. Prvi je postojanje nacionalnih postupaka kojima je cilj nametanje mjera preventivne ili kaznene naravi određenim osobama u vezi s borbom protiv terorizma, zbog umiješanosti tih osoba u terorističke aktivnosti. Drugi je donošenje i provođenje odluke nadležnog nacionalnog tijela, koje treba ispunjavati navedene uvjete, kojom se dotična osoba osuđuje zbog takvih aktivnosti. Sukladno tome, Sud EU-a tvrdio je da Zajedničko stajalište

32 Vidi, npr. presudu Suda Europske unije Fulmen i Fereydoun Mabmoudian protiv Vijeća Europske unije, T-439/10 i T-440/10, ECLI:EU:T:2012:142, 21. 3. 2012. (dalje: Fulmen I).

${ }^{33}$ Presuda Suda Europske unije Petropars Iran Co. i dr. protiv Vijeća Europske unije, T-433/13, ECLI:EU:T:2015:255, 5.5.2015., para 31.-48., Ayadi I, para 160.-170., OMPI I, para 141.-143., presuda Suda Europske unije Stichting Al-Aqsa protiv Vijeća Europske unije, T-327/03, ECLI:EU:T:2007:211, 11. 7. 2007. (dalje: Al-Aqsa I), para 53.-67., presuda Suda Europske unije Jose Maria Sison protiv Vijeća Europske unije, T-341/07, ECLI:EU:T:2011:687, 23. 11. 2011. (dalje: Sison III), para 59.-61. Vidi i Fulmen I, para 51.-62. i presudu Suda Europske unije People's Mojahedin Organization of Iran protiv Vijeća Europske unije, T-284/08 ECLI:EU:T:2008:550, 4. 12. 2008. (OMPI III), para 71.-73. 
2001/931 ne zahtijeva da odluka nadležnog tijela bude donesena u okviru kaznenog postupka, iako je to najčešće. Međutim, s obzirom na ciljeve koje slijedi navedeno Zajedničko stajalište, cilj nacionalnog postupka o kojem se radi mora biti borba protiv terorizma u najširem smislu. Točnije, ta odluka mora biti donesena u okviru nacionalnog postupka čiji je neposredni i glavni cilj određivanje preventivne ili represivne mjere protiv dotičnih osoba, skupina ili subjekata u vezi s borbom protiv terorizma i zbog uključenosti u terorizam. Takav zahtjev ne ispunjava odluka nacionalnog tijela koja samo podredno i incidentalno odlučuje o mogućoj uključenosti dotične osobe, skupine ili subjekta u takvu aktivnost, u okviru koje se odnosi na prava i obveze građanskoga karaktera (LTTE, para 111.-116.).

Tako je i u presudi Sison III Opći sud konstatirao da takva odluka treba, izravno i prvenstveno, osobi o kojoj je riječ nametati sankcije preventivne ili čak kaznene naravi, u vezi s borbom protiv terorizma i zbog povezanosti te osobe s terorizmom, što neće biti zadovoljeno ako se ta odluka tim pitanjem bavi tek uzgredno i neizravno. U konkretnom slučaju, nacionalne odluke na koje se pozivalo Vijeće EU-a nisu ni na koji način bile povezane s kažnjavanjem eventualne povezanosti g. Sisona sa sudjelovanjem u terorističkim aktivnostima, već su se odnosile na nadzor zakonitosti odluke kojom mu je odbijen zahtjev za stjecanje statusa izbjeglice i stalni boravak (Sison III, para 111.-113.). ${ }^{34}$

U slučaju odluke o zadržavanju imena na relevantnom popisu, odnosno naknadne odluke o primjeni mjere ograničavanja, riječ je o utvrđivanju je li mjera zamrzavanja imovine i dalje opravdana, uzevši u obzir sve relevantne okolnosti slučaja. Kad su osnove za usvajanje takve odluke o zamrzavanju imovine u osnovi jednake kao one za usvajanje inicijalne odluke, dovoljna je samo izjava u tom smislu, pogotovo ako je riječ o grupi, odnosno organizaciji (OMPI II, para 78.-86.; Fabas, para 51.-62.; Sison III, para 62.).

Nadalje, ono što je Sud EU-a naglasio jest da pitanje je li postupljeno sukladno obvezi obrazlaganja treba razlikovati od pitanja kvalitete tih obrazlaganja, odnosno pitanja jesu li dokazi na koje se Vijeće EU-a oslanjalo utvrđeni i opravdavaju li usvajanje mjera ograničavanja o kojima je riječ..$^{35}$ Sud EU-a istaknuo je potrebu razlikovanja obveze obrazlaganja akta kao

34 Vidi i presudu Suda Europske unije Sofiane Fahas protiv Vijeća Europske unije, T-49/07 ECLI:EU:T:2010:499, 7. 12. 2010. (dalje: Fabas), para 55.

35 Presuda Suda Europske unije Vijeće Europske unije protiv Nadiany Bamba, C-417/11 ECLI:EU:C:2012:718, 15. 11. 2012. (Bamba II), para 55.-61. 
formalnog preduvjeta i pitanja utemeljenosti razloga, što je dio meritorne zakonitosti osporavanog akta. Naime, obrazloženje akta sastoji se od formalnog navođenja razloga na kojima se taj akt temelji. Ako ti razlozi imaju nedostatke, ti nedostaci negativno utječu na meritornu zakonitost akta, ali ne i na njegovu obrazloženost. Uvjet obrazloženosti, objašnjava Opći sud, može biti zadovoljen i ako navodi pogrešne razloge. ${ }^{36}$

S druge strane, Sud EU-a smatrao je da osim što formalna obveza iz čl. 296. UFEU-a mora biti zadovoljena, osobe odnosno entiteti kojih se to tiče moraju biti obaviješteni odnosno poučeni o tim istim razlozima. U predmetu Bank Melli I nije prihvatio shvaćanje Vijeća EU-a prema kojem je toj obvezi udovoljeno objavljivanjem odluke u Službenom listu Europske unije. Ipak, zaključio je da u iznimnim okolnostima ovog slučaja, u kojima je tužitelja Francuska bankarska komisija ipak obavijestila o usvajanju osporavane odluke i njezinu objavljivanju u Službenom listu Europske unije, činjenica što Vijeće EU-a nije poučilo tužitelja o pojedinačnoj obavijesti o razlozima za usvajanje navedene odluke, nije rezultiralo njegovim neznanjem o tome. Posljedično, zaključio je da taj propust Vijeća EU-a ne opravdava poništavanje osporavane odluke. Također, Sud je primijetio da se ne traži da obavijest na koju se odnosi ima određeni oblik. ${ }^{37} \mathrm{U}$ svakom slučaju, Vijeće EU-a obvezno je obavijestiti o svojoj odluci zainteresirane osobe, kao i o osnovama za usvajanje odluke o primjeni sankcija. To treba učiniti ili izravno, dostavom na kućnu adresu, ili putem objavljivanja obavijesti kako bi zainteresirana osoba bila u mogućnosti podnijeti vlastita očitovanja. ${ }^{38}$

Što se tiče trenutka kada osobi odnosno entitetu prema kojem se mjere ograničavanja primjenjuju treba dostaviti obrazloženje, Sud EU-a odredio je da će to, kod inicijalnih odluka odnosno odluka o upisu imena na popis biti istovremeno s usvajanjem odluke ili odmah potom kako bi se ostvario efekt iznenađenja potreban za ostvarivanje efikasnosti odluke. Kod naknadnih odluka odnosno kod odluka o zadržavanju imena na popisu, to će biti prije usvajanja odluke. Razlog za to je da bi osobe o kojima je riječ

${ }^{36}$ Presuda Suda Europske unije Syrian Lebanese Commercial Bank SAL protiv Vijeća Europske unije, T-174/12 i 80/13, ECLI:EU:T:2014:52, 4. 2. 2014. (SAL), para 81.-87.

${ }^{37}$ Presuda Suda Europske unije Bank Melli Iran protiv Vijeća Europske unije, T-390/08, ECLI:EU:T:2009:401, 14. 10. 2009. (Bank Melli Iran I), para 79.-90. i presuda Bank Melli Iran protiv Vijeća Europske unije, C-548/09 P, ECLI:EU:C:2011:735, 16.11.2011. (Bank Melli Iran II), para 47.-57.

38 Presuda Suda Europske unije Tarif Akbras protiv Vijeća Europske unije, T-579/11 R ECLI:EU:T:2015:97, 12. 2. 2015. (dalje:: Akbras), para 74.-90. 
mogle na najbolji mogući način braniti svoja prava i, s potpunim saznanjem o relevantnim činjenicama, odlučiti ima li smisla obratiti se sudstvu Europske unije, kao i omogućiti upravo tom sudstvu da izvrši odgovarajući nadzor zakonitosti mjere o kojoj se radi. ${ }^{39}$

Dakle, možemo konstatirati da, iako je uvijek inzistirao na određenoj razini kvalitete obrazloženja sukladno obvezi obrazlaganja navedenoj u UFEU-u, a razrađenoj kroz njegovu praksu, Sud je postavio pravilo da je dovoljno da je tužitelj mogao razumjeti obrazloženje i da su mu relevantni podaci bili poznati kako bi se smatralo da je obvezi čl. 296. UFEU-a udovoljeno. ${ }^{40}$

Učinkovit sudski nadzor, u smislu pitanja je li udovoljeno obvezi o kojoj je riječ, podrazumijeva provjeru činjenica navedenih u obrazloženju odluke kako sudski nadzor ne bi bio ograničen samo na utvrđenje apstraktne vjerojatnosti razloga, nego i na saznanje o tome jesu li oni dokazani, ili je li barem jedan od njih, koji se smatra dostatnim da se na njemu može zasnivati ta odluka, dokazan. Sud EU-a mora obaviti takvo ispitivanje te pritom zahtijevati, po potrebi, da nadležno tijelo Unije podnese podatke ili dokaze relevantno za takvo ispitivanje, bez obzira na to jesu li oni povjerljivi ili ne. Dakle, teret dokazivanja je na dotičnom tijelu Unije, s obzirom na to da upravo ono, u slučaju osporavanja, ima dužnost utvrditi osnovanost razloga sakupljenih protiv osobe koje se to tiče, pri čemu nije potrebno da se Sudu EU-a podnesu svi podaci i dokazi, ali je potrebno da pruženi podaci i dokazi podrže razloge protiv dotične osobe. ${ }^{41}$

Ako nadležno tijelo Unije ne može postupiti po zahtjevu Suda EU-a, tada će taj Sud svoju odluku temeljiti samo na onim elementima koji su mu priopćeni odnosno na naznakama koje sadržava obrazloženje Odbora 1267, očitovanjima i oslobađajućim dokazima eventualno podnesenim od osobe koje se to tiče kao i na odgovoru nadležnog tijela na ta očitovanja. S tim u vezi, postavljeno je pravilo da ako navedeni elementi ne omogućavaju

39 Presuda Suda Europske unije Francuska protiv People's Mojabedin Organization of Iran, C-27/09 P ECLI:EU:C:2011:853 (OMPI IV), 21. 12. 2011., para 64.-66, presuda Suda Europske unije Kongra-Gel i drugi protiv Vijeća Europske unije, T-253/04, ECLI:EU:T:2008:88, 3. 4. 2008. (KONGRA-GEL), para 95.-105., presuda Suda Europske unije Manufacturing Support \& Procurement Kala Naft Co., Tebran protiv Vijeća Europske unije, T-509/10, ECLI:EU:T:2012:201, 25. 4. 2012. (KALA NAFT I), para 106.-110.

${ }^{40}$ Presuda Suda Europske unije Vijeće Europske unije protiv Manufacturing Support \& Procurement Kala Naft Co., Tebran, C-348/12 P, ECLI:EU:C:2013:776, 28. 11. 2013. (dalje:: KALA NAFT II), para 72. i 91.-93.

41 Presuda Suda Europske unije Chafiq Ayadi protiv Europske komisije, T-527/09 RENV ECLI:EU:T:2015:205, 14. 4. 2015. (dalje:: Ayadi IV), para 61.-66. 
ustanoviti osnovanost nekog razloga, Sud EU-a neće ga uzeti u obzir kao temelj odluke o primjeni mjere ograničavanja. Međutim, ako nadležno tijelo pruži relevantne dokaze ili podatke, Sud EU-a mora provjeriti točnost sadržaja navedenih činjenica i utvrditi njihovu dokaznu snagu ovisno o okolnostima slučaja i s obzirom na podnesena očitovanja. Pritom Sud EU-a mora provoditi metode koje omogućuju pomirenje legitimne sigurnosne prosudbe o prirodi i izvorima informacija koji su uzeti u obzir prilikom donošenja dotičnog akta i potrebe jamčiti dovoljno poštovanja postupovnih prava. Potrebno je posebno istaknuti da ako Sud EU-a utvrdi da je barem jedan od razloga iz obrazloženja Odbora 1267, kada je riječ o implementiranim sankcijama, dovoljno precizan i konkretan, dokazan i predstavlja dovoljnu osnovu za usvajanje odluke o mjeri ograničavanja o kojoj je riječ, okolnost da ostali razlozi ne zadovoljavaju ove uvjete ne opravdava poništenje te odluke.

Prema shvaćanju Suda EU-a, činjenica da osobi o kojoj je riječ ili Sudu EU-a nisu bili dostupni podaci i dokazi koji se odnose na obrazloženje predmetne odluke te koji su u isključivom posjedu Ujedinjenih naroda ne može sama po sebi tvoriti povredu prava na obranu i na učinkovitu sudsku zaštitu. U takvoj situaciji Sud EU-a, uzimajući u obzir oslobađajuće dokaze koje je eventualno podnijela osoba koje se to tiče, kao i odgovor nadležnog tijela Unije, neće raspolagati dodatnim podacima ili dokazima. Nastavno na navedeno, ako neće moći utvrditi osnovanost tih razloga, oni neće moći, prema zaključcima Općeg suda, niti služiti kao temelj za donošenje odluke o kojoj je riječ (vidi Ayadi IV, para 61.-66., i Abdulrabim III, para 62.-71., Kala Naft II, para 72. i 91.-93.). Sud EU-a, dakle, ne traži izravno dostavljanje svih relevantnih podataka, ali to čini neizravno konstatirajući da ako neće moći utvrditi osnovanost tih razloga, ti razlozi neće moći niti služiti kao temelj za donošenje odluke.

Konačno, možemo konstatirati i da Sud EU-a nije uvijek bio toliko strog prema Vijeću EU-a. Tako je konstatirao i da se od Vijeća EU ne može tražiti da s većom preciznošću odredi na koji će način zamrzavanje imovine osobe odnosno entiteta doprinijeti borbi protiv terorizma odnosno da podnese dokaze kako bi ta osoba odnosno entitet mogao iskoristiti svoju imovinu za počinjenje ili pomaganje počinjenju terorističkih djela (Sison III, para 64. i 65.; Fabas, para 57.).

Nadalje, dopustio je, pod određenim uvjetima, i upotrebu presumpcija u dokazivanju. Tako je bilo u predmetu Anbouba I u kojem je Vijeće EU-a na tužitelja primijenilo presumpciju da se rukovoditelji glavnih sirijskih poduzeća mogu kvalificirati kao osobe povezane sa sirijskim režimom, s obzirom na to da se poslovanje tih poduzeća ne bi moglo uspješno razvi- 
jati bez uživanja naklonosti sirijskog režima i ako mu ti poduzetnici ne bi pružali određenu potporu. Opći sud je naglasio da se presumpcija, čak i kad je teško oboriva, nalazi u granicama dopuštenog ako je proporcionalna legitimnom cilju kojem teži, ako postoji mogućnost podnošenja dokaza o protivnom i ako je osigurano pravo na obranu, pozivajući se pritom i na odluku Suda u presudi predmeta Tay Za II. ${ }^{42}$ Sud EU-a u žalbenom je postupku ustvrdio da upućivanje na presumpciju potpore sirijskom režimu ne može utjecati na zakonitost pobijane presude, s obzirom na to da je Opći sud u dovoljnoj mjeri ispitao postoji li dovoljno čvrsta osnova za primjenu mjera ograničavanja prema g. Anboubiju (Anbouba I, para 39.-59.). Slično je bilo i u predmetu Akbras (Akbras, para 109.-135.).

Postavljajući ovakva pravila, Sud EU-a ponekad je podržao primjenu mjera ograničavanja, a ponekad je onemogućavao njihovu primjenu (Van den Berghe, 2010., str. 133). Otežavanje provođenja mjera ograničavanja od strane Suda EU-a ne sastoji se u osporavanju odluka o njihovu provođenju od strane sudstva Europske unije, već u samoj činjenici potpunog nadzora i postupku koji s tim u vezi Sud EU-a provodi.

Kada je riječ o implementiranim mjerama ograničavanja, otežavanje se sastoji u postavljanju strogih uvjeta VSUN-u u smislu zaštite procesnih prava osoba odnosno entiteta pogođenih mjerama ograničavanja, bez čijeg ispunjavanja Sud EU-a neće podržati te mjere ograničavanja. Uz to, kao što je navedeno, države članice Europske unije, koje su sve i članice Ujedinjenih naroda, dovedene su u nezahvalnu situaciju u kojoj se moraju oglušiti ili o svoje obveze prema VSUN-u ili o presude Suda EU-a (v. Stenhammar, 2010., str. 137). Ako odluče pokoriti se presudama Suda EU-a, provođenje mjera ograničavanja na koje se odnosi konkretna presuda bit će onemogućeno ili barem otežano (v. Wimmer, 2014., str. 702).

Kada je riječ o autonomnim mjerama Europske unije, i ovdje je provođenje tih mjera u najmanju ruku usporeno, s obzirom na dodatne uvjete za opstojnost i provođenje mjera ograničavanja koje Sud EU-a postavlja državama članicama. Ne dovodeći u pitanje važnost zaštite prava osoba odnosno entiteta prema kojima se mjere ograničavanja o kojima je riječ provode, činjenica je da je Sud EU-a utjecao i utječe na njihovu efikasnost.

42 Presuda Suda Europske unije Issam Anbouba protiv Vijeća Europske unije, T-563/11 ECLI:EU:T:2013:429,13.9.2013. (dalje: Anbouba I), para 31.-44., presuda Suda Europske unije Pye Phyo Tay Za protiv Vijeća Europske unije, C-376/10 P, ECLI:EU:C:2012:138, 13. 3. 2012. (Tay Za II), para 69. 


\section{Zaključak}

Provođenje sankcija odnosno mjera ograničavanja protiv pojedinih osoba odnosno entiteta u smislu ovog rada nužno dovodi do ograničavanja određenih prava tih osoba, zaštićenih relevantnim međunarodnim izvorima kao što su Europska konvencija za zaštitu ljudskih prava i temeljnih sloboda ili Povelja Europske unije o temeljnim pravima.

Kada je riječ o mjerama zamrzavanja imovine, u prvom će se redu raditi o ograničavanju prava vlasništva te obavljanja gospodarske djelatnosti. Sud EU-a u provođenju nadzora nad primjenom takvih mjera odnosno sankcija, provjeravao je, između ostalog, i je li prilikom njihove primjene došlo do neprimjerenih ili prekomjernih ograničenja tog prava.

Kako proizlazi iz gore prikazane prakse, Sud EU-a smatrao je da pravo vlasništva, odnosno njegova realizacija, može biti ograničeno, pod pretpostavkom da ta ograničenja odgovaraju ciljevima javnog interesa koji Europska unija želi ostvariti te da, s obzirom na te ciljeve, ne predstavljaju neproporcionalnu smetnju njegove realizacije.

$\mathrm{S}$ druge strane, u najvećoj mjeri bila je riječ o povredi postupovnih prava, točnije prava na obranu u širem smislu riječi, prava na saslušanje (uključujući i pravo na pristup sudu) i prava na učinkovito pravno sredstvo, kao i, u vrlo velikom broju slučajeva, obvezi obrazlaganja akata kojima se sankcije nameću. Dakle, radi se o onim pravima koja se u stranoj terminologiji nazivaju due process.

Mjere ograničavanja odnosno sankcije koje su predmet ovog rada bile su nametane osobama odnosno entitetima povezanim s terorizmom odnosno financiranjem terorističkih aktivnosti, proliferacijom nuklearnog oružja te s nasilnom represijom nad civilnim stanovništvom. Međutim, te osobe odnosno entiteti nisu uvijek bili jedini „objekti“ sankcija. Nije bila samo riječ o osobama konkretno povezanim s terorizmom ili vladajućim režimima pojedinih država prema kojima su se mjere ograničavanja primjenjivale, već i o članovima njihovih obitelji. Isto tako, Sud EU-a se pitanjem „pasivne legitimacije" za primjenu mjera ograničavanja, odnosno sankcija te „aktivne legitimacije“ za podnošenje tužbi protiv odluka na temelju kojih su se one primjenjivale bavio i s obzirom na pravne osobe, organizacije, pa čak i oslobodilačke pokrete trećih zemalja (v. predmete Tay Za ili LTTE). Uz taj, „personalni aspekt“ možemo govoriti i o „vremenskom aspektu“ nadzora Suda EU-a. „Vremenski aspekt“ nadležnosti Suda EU-a u nadzoru nad primjenom mjera ograničavanja odnosi se na vremenski okvir u kojemu su nastale odluke kojima su se navedene mjere određivale te 
koje su pojedinci odnosno entiteti pogođeni tim mjerama pobijali. U tom smislu, Sud EU-a često je ocjenjivao postojanje pravnog interesa tužitelja s obzirom na činjenicu da su odluke kojima su im mjere ograničavanja nametnute naknadno stavljene izvan snage (vidi predmete Abdulrabim II ili Ayadi III).

U sadržajnom smislu, Sud EU-a pogotovo je štitio pravo na obranu u širem smislu riječi. Tako je smatrao da pravo na saslušanje treba biti, u prvom redu, realizirano na nacionalnoj razini. $U z$ to, razlikovao je ostvarivanje tog prava ovisno o tome je li riječ o inicijalnim ili naknadnim odlukama o zamrzavanju imovine te dopuštao stanovita ograničavanja tog prava kad je riječ bila o potonjima, kako bi se sačuvao tzv. efekt iznenađenja.

U slučaju prvih, Vijeće EU-a nije obvezno odmah obavijestiti osobu odnosno entitet o kojem je riječ o osnovama na temelju kojih namjerava usvojiti odluku o primjeni takve mjere prema dotičnim osobama odnosno entitetima. Naime, na taj bi način učinkovitost te mjere bila ugrožena jer ona ne bi mogla iskoristiti tzv. efekt iznenađenja. U takvim situacijama obavijest je dovoljna istovremeno s usvajanjem takve mjere odnosno odmah potom. Drugačije je kod naknadnih odluka, odnosno odluka o zadržavanju konkretnog imena na popisu subjekata na koje se mjera odnosi, s obzirom na nepostojanje daljnje potrebe efekta iznenađenja. Usvajanju takvih odluka mora prethoditi obavijest o tome osobi odnosno entitetu o kojem je riječ, kao i omogućavanje toj osobi odnosno entitetu da budu saslušani (OMPI IV, para 61. i 62; v. Hollenberg, 2015., str. 53).

Nadalje, Sud EU-a inzistirao je i na učinkovitom sudskom nadzoru koji podrazumijeva provjeru činjenica navedenih u obrazloženju odluke koja se osporava, a kako sudski nadzor ne bi bio ograničen samo na utvrđenje apstraktne vjerojatnosti razloga, nego i na saznanje o tome jesu li oni dokazani, ili je li barem jedan od njih koji se smatra dostatnim da se na njemu može zasnivati ta odluka, dokazan (Ayadi IV, para 61.-66.).

Posebno je štitio i obvezu obrazlaganja akata iz čl. 296. UFEU-a te naglašavao da obveza obrazlaganja akta koji pogađa neku osobu proizlazi iz načela poštovanja prava na obranu. Obvezni sadržaj obrazloženja različit je ovisno o tome je li riječ o inicijalnim ili naknadnim sankcijama.

Konkretno, u slučaju obrazloženja za donošenje inicijalne odluke o zamrzavanju imovine, dakle odluke o upisu imena na popis subjekata na koje se mjera odnosi, ono se u najmanju ruku mora odnositi na pitanje postoji li specifičan podatak ili materijal u odgovarajućoj dokumentaciji koji upućuje na to da je odluku u vezi s tim osobama, skupinama i subjektima donijelo nadležno tijelo. 
U slučaju obrazloženja za donošenje naknadne (kasnije) odluke, dakle odluke o zadržavanju konkretnog imena na popisu subjekata na koje se mjera odnosi, ona mora sadržavati točne i specifične razloge koji upućuju na to zašto Vijeće EU-a smatra da je u konkretnom slučaju daljnja primjena sankcije opravdana. Može se zaključiti da obrazloženje za mjeru o zamrzavanju imovine, u svakom slučaju, mora obuhvaćati razloge zašto je Vijeće EU-a, u sklopu svojih diskrecijskih ovlasti, smatralo da dotična mjera treba biti usvojena (Van den Berghe, 2010., str. 133; Tridimas \& Gutierrez-Fons, 2009., str. 716-718; OMPI I, para 144.-151.; vidi i Sison II, para 191.-198.).

Međutim, pitanje je li postupljeno sukladno obvezi obrazlaganja treba razlikovati od pitanja kvalitete tih obrazlaganja, odnosno pitanja jesu li dokazi na koje se Vijeće EU-a oslanjalo utvrđeni i opravdavaju li usvajanje mjera ograničavanja o kojima je riječ (v. predmet Bamba II, para 55.-61.). U svakom slučaju, prilikom zaštite tih prava, Sud EU-a provodio je tzv. postupak uravnotežavanja koji, zapravo, predstavlja primjenu načela proporcionalnosti. To načelo, kao jedno od općih načela prava Europske unije, zahtijeva da mjere njezinih institucija ne prekorače granice onog što je primjereno i potrebno za postizanje legitimnih ciljeva njezina zakonodavstva. To, nadalje znači da kad postoji izbor između više primjerenih mjera, treba prisegnuti za onom najmanje otežavajućom, s time da nedostaci njome uzrokovani ne smiju biti neproporcionalni cilju koji se želi postići. ${ }^{43}$ Takvom praksom Sud EU-a uistinu je potvrdio svoju ulogu zaštitnika postupovnih prava osoba na koje se sankcije odnose (Shirlow, 2014., str. 25). Zapravo, može se reći da svoju nadležnost Sud nije u tolikoj mjeri utemeljio na nepostojanju adekvatne zaštite ljudskih prava koliko na autonomiji vlastitog poretka u odnosu prema međunarodnom pravnom poretku (Shi-

${ }^{43}$ Presuda Suda Europske unije H. Jippes, Afdeling Groningen van de Nederlandse Vereniging tot Bescherming van Dieren $i$ Afdeling Assen en omstreken van de Nederlandse Vereniging tot Bescherming van Dieren protiv Minister van Landbouw, Natuurbeheer en Visserij, zabtjev za prethodnu odluku: College van Beroep voor het bedriifsleven - Nizozemska, C-189/01 ECLI:EU:C:2001:420, 12. 7. 2001., para 81., presuda Suda Europske unije The Queen, na zahtjev S.P.C.M. SA, C.H. Erbslöb KG, Lake Chemicals and Minerals Ltd i Hercules Inc. protiv Secretary of State for the Environment, Food and Rural Affairs, zabtjev za prethodnu odluku: High Court of Justice (England \& Wales), Queen's Bench Division (Administrative Court) - Ujedinjeno Kraljevstvo, C558/07 ECLI:EU:C:2009:430, 7. 7. 2009., para 86., presuda Suda Europske unije Industria Lavorazione Carni Ovine Srl protiv Regione Lazio, zahtjev za prethodnu odluku: Corte suprema di cassazione - Italija, C534/06 ECLI:EU:C:2008:319, 5. 6. 2008., para 41. Vidi i presudu Suda Europske unije Volker und Markus Schecke GbR (C-92/09) i Hartmut Eifert (C-93/09) protiv Land Hessen, zahtjevi za prethodnu odluku: Verwaltungsgericht Wiesbaden - Njemačka, C-92/09 i C-93/09 ECLI:EU:C:2010:662, 9. 11. 2010. 
rlow, 2014., str. 14). U tom kontekstu bilo bi zanimljivo postaviti pitanje je li ovdje riječ o iskrenoj brizi Suda EU-a za zaštitu ljudskih prava ili je ipak riječ o njegovoj težnji da ojača položaj Europske unije na međunarodnom planu (Isiksel, 2010., str. 567; Cremona, 2009., str. 589).

Konačno, jedan od većih problema koji se javlja u kontekstu inzistiranja na zaštiti ljudskih prava kod provođenja mjera ograničavanja jest i pitanje narušavanja autoriteta Ujedinjenih naroda i odnosa snaga u međunarodnoj zajednici (Orakhelashvili, 2015., str. 19). Naime, države članice Europske unije mogle bi se naći u nezahvalnoj situaciji jer bi Sud EU-a od njih mogao tražiti da, u slučaju da sruši odluku o primjeni sankcija UN-a, „otkažu poslušnost“ Ujedinjenim narodima (Marguiles, 2014., str. 62). Tako bi Sud EU-a praktički prisiljavao države članice da postupe suprotno članku 103. Povelje UN-a. Taj članak daje isključivu prednost obvezama iz Povelje UN-a pred obvezama iz svih drugih međunarodnih sporazuma. Ključ u rješavanju ovog problema leži u kvalitetnoj međunarodnoj suradnji (Derenčinović, 2002., str. 562) odnosno većem stupnju međusobnog povjerenja (u tom smislu vidi i Marguiles, 2014., str. 58; sl. i Marossi, 2015., str. 176), koje bi se trebalo temeljiti na poštovanju relevantnih odredbi i pravila međunarodnog, ali i europskog prava. Upravo odredbe čl. 24., 25. i 103. Povelje UN-a, ali i relevantne odredbe Ugovora o Europskoj uniji i Ugovora o funkcioniranju Europske unije ${ }^{44}$ trebale bi tvoriti tu granicu koju, u svojem nadzoru, Sud EU-a ne bi smio prijeći.

U tom kontekstu najpomirljivijim čini se pristup nezavisnog odvjetnika Bota, usmjeren k suradnji Ujedinjenih naroda i Europske unije u ovom pitanju (Mišljenje Kadi IV, para 71. i 85.; vidi i Morgan, 2013., str. 5). Prema njemu, nadzor Suda EU-a je nužan, ali i ograničen u smislu ,nepotkopavanja" sustava sankcija VSUN-a, tijela kojem je povjerena središnja uloga u zaštiti međunarodnog mira i sigurnosti (u tom smislu v. Marguiles, 2014., str. 55).

\section{Literatura}

Anthony, I. (2002). Sanctions applied by the European Union and united nation. Stockholm International Peace Reasearch Institute. Preuzeto sa: https://www.sipri.org/yearbook/2002/05

Canor, I. (1998). Can two walk together, except they be agreed? The relationship between international law and European law: The incorporation of United

${ }^{44}$ Npr. čl. 4., 5. i 40. UEU-a te 215. i 346. UFEU-a. 
Nation sanctions against Yugoslavia into European Community law through the perspective of the European Vourt of Justice. Common Market Law Review, 35(1), 137-187, https://doi.org/10.1023/a:1018371032655

Cardwell P.J. (2015). The legalisation of European Union foreign policy and the use of sanctions. Cambridge Yearbook of European Legal Studies, 17(1), 287310, https://doi.org/10.1017/cel.2015.11

Cousins, M. (2008). Asset freezing, social security and human rights analysis. Kings law Journal, 19(2), 402-411, https://doi.org/10.1080/09615768.2008.1 1423677

Cremona, M. (2009). EC competence, „smart sanctions“ and the Kadi Case. Yearbook of European Law, 28(1), 559-592, https://doi.org/10.1093/yel/28.1.559

Crnić-Grotić, V., \& Sgardelli Car, N. (2010). Ljudska prava u Europskoj uniji u praksi Europskog suda u Luksemburgu. Zbornik Pravnog fakulteta u Zagrebu, 60(5), 971-994.

Derenčinović, D. (2002). Novi antiterorizam na razmeđu depolitizacije i dejuridizacije. Zbornik Pravnog fakulteta u Zagrebu, 52(3-4), 545-573.

Eckes, C. (2012). Decision making in the Dark? Autonomous EU Sanctions and national classification. Amsterdam centre for European Law and governance. University of Amsterdam, Research Paper No. 2012-02, https://doi.org/10.2139/ ssrn.2075794

Eckes, C., \& Mendes J. (2011). The right to be heard in composite administraitve procedures: lost in between protection? European Law Review, 36(5), 651-670.

Eeckhout, P. (2011). EU external relations law. New York, United States, Oxford University Press

Genser, J. \& Barth, K. (2010). When due process concerns become dangerous: the security council's 1267 regime and the need for reform. Boston College International and Comparative Law, 33(1), 1-41.

Gutherie, P. (2004). Security Council sanctions and the protection of individual rights. New York University Annual Survey of American Law, 69(3), 491-541.

Hollenberg, S. (2015) The Security Council's 1267/1989 targeted sanctions regime and the use of confidential information: a proposal for decentralization of review. Leiden Journal of International Law, 28(1), 49-71, https://doi. org/10.1017/s0922156514000533

Heliskoski, J. (2007). Case T-253/02, Chafiq Ayadi v Council, Judgment of the Court of First Instance of 12 July 2006; Case T-49/04, Faraj Hassan v Council and Commission, Judgment of the Court of First Instance of 12 July 2006. Common Market Law Review, 44(4), 1143-1157.

Isiksel, T. (2010). Fundamental rights int he EU after Kadi and Al Barakaat. European Law Journal, 16(5), 551-577, https://doi.org/10.1111/j.14680386.2010.00522.x

Lapaš, D. (2004). Sankcija u međunarodnom pravu. Zagreb, Hrvatska: Pravni fakultet u Zagrebu

Leenders, L (2014.). EU sanctions: a relevant foreign policy tool?. EU Diplomacy Paper, 3/2014, 1-40. 
Marguiles, P.(2014). Aftermath of an unwise decision: The U.N. terrorist sanctions regime after Kadi II. Amsterdam Law Forum, 6(2), 51-63.

Marossi Z.A. (2015). Unilateralism and power of revision. U Z. A. Marossi, M. R. Bassett (ur.), Economic sanctions under international law (str. 165-177). The Hague, The Netherlands: t.m.c. asser press, https://doi.org/10.1007/978-946265-051-0_9

Misheva K. \& Duić, D. (2015). The EU restrictive measures-what if the Court of Justice of European Union finds them not being legal: Cases in Croatia and Republic of Macedonia. Balkan Social Science Review, 6, 21-41.

Morgan, G. (2013). The Kadi Saga: UN targeted asset-freezing sanctions under scrunity. Preuzeto sa: EU Law Blog, King's Student Law Review (KSLR) Blog on European Law, https://blogs.kcl.ac.uk/kslreuropeanlawblog/?p=461\#.VnQU-0841ec

Murphy, C. (2011). Case C-117/06, Proceedings brought by Gerda Möllendorf and Christiane Möllendorf-Niehuus, Judgment of the European Court of Justice (Second Chamber) of 11 October 2007, [2007] ECR I-8361; Case C-340/08, M \& Others v Her Majesty's Treasury, Judgment of the European Court of Justice (Fourth Chamber) of 29 April 2010, nyr; Case C-550/09, Criminal Proceedings Against E \& F, Judgment of the European Court of Justice (Grand Chamber) of 29 June 2010. Common Market Law Review, 48(1), 243.-264., https://doi.org/10.5040/9781509911196.ch-008

Orakhelashvili, A. (2015). The Impact of unilateral EU economic sanctions on the UN collective security framework: The Cases of Iran and Syria. U Z. A. Marossi, M. R. Bassett (ur.), Economic sanctions under international law, (str. 3-21). The Hague, The Netherlands: t.m.c. asser press, https://doi. org/10.1007/978-94-6265-051-0_1

Portela C., (2014). The EU's use of „targeted“ sanctions, evaluating effectiveness. CEPS Working Documents, 391, 1-45.

Puissochet, J-P (1997). The Court of Justice and international action by the European Community: the example of the embargo againts former Yugoslavia. Fordhaminternational Law Journal, 20(5), 1557-1576.

Shirlow, E. (2014). Taking stock: assesing the implications of the Kadi Saga for international law and the law of the European Union. Melbourne Journal of International Law, 15(2), 534-559.

Stenhammar, F. (2010). United nations targeted sanctions, the international rule of law and the European Court of Justice's Judgment in Kadi and Al-Barakaat. Nordic Journal of International Law, 79(1), 113-140, https://doi.org/10.1 163/157181009x12581245929686

Tridimas, T., Gutierrez-Fons, J.A. (2009). EU Law, International Law and Economic Sanctions Against Terrorism: the judiciary in distress?, Fordham International Law Journal, 32(2), 660-730.

Tzanakopoulos, A. (2014). The solange argument as a justification for disobeying the security council in the Kadi judgements. U M. Avbelj, F. Fontanelli F. \& G. Martinico Kadi on trial: A multifaceted analysis of the Kadi judgment (str. 121134). Abington, UK: Routledge, https://doi.org/10.4324/9780203796191-10 
Tzanakopoulos, A. (2015). Sanctions imposed unilaterally by the European Union: Implications for the European Union's international responsibility. U Z. A. Marossi, \& M. R. Bassett (eds.), Economic sanctions under international law (str. 145-161). The Hague, The Netherlands: Asser Press, https:// doi.org/10.1007/978-94-6265-051-0_8 van den Berghe, F. (2010). The EU and issues of human rights protection: Same Solutions to more acute problems?. European Law Journal, 16(2), 112-157, https://doi.org/10.1111/j.14680386.2009.00501.x

Willis, G. (2010). Security Council targeted sanctions, due process and the 1267 Ombudsperson. From the selected works of Grant L Willis (str. 3-40). Preuzeto sa: https://pdfs.semanticscholar.org/5673/0609d9ff433a6886536b6b9c8f47ea56b928.pdf?_ga $=2.48371886 .943493464 .1567587494$ 652377592.1567587494

Wimmer, M. (2014). Inward-and outward-looking rationales behind Kadi II. Maastrich Journal of European and Comparative Law, 21(4), 676-703, https:// doi.org/10.1177/1023263x1402100406

\section{Pravni propisi}

Ugovor o Europskoj uniji i Ugovor o funkcioniranju Europske unije (pročišćene verzije) 2010/C 83/01(Lisabonski ugovor) preuzeto s http://www.mvep.hr/ custompages/static/hrv/files/pregovori/111221-lisabonski-prociscena.pdf

Povelja UN-a, NN 15/93

Bečka konvencija o pravu međunarodnih ugovora , NN- Međunarodni ugovori, $16 / 93$

Zakon o međunarodnim mjerama ograničavanja, NN 139/08, 41/14

\section{Presude Suda EU i Mišljenja nezavisnih odvjetnika}

Presuda Suda EU, Petropars Iran Co. i dr. protiv Vijeća Europske unije, T-433/13, ECLI:EU:T:2015:255, 5.5.2015

Presuda Suda Europske unije 30. 7. 1996. Bosphorus Hava Yollari Turizm ve Ticaret AS protiv Minister for transport energy and communications $i d r$., Zabtjev za prethodnu odluku: Supreme Court-Irska C-84/95, ECLI:EU:C:1996:312 , 30. 7. 1996.

Presuda Suda Europske unijeBušra alAsad protiv Vijeća Europske unije, T-202/12 ECLI:EU:T:2014:113, 12. 3. 2014.

Presuda Suda Europske unije, Stichting Al-Aqsa i Nizozemska Kraljevina protiv Vijeća Europske unije, C-539/10 P i 550/10 P, ECLI:EU:C:2012:711, 15. 11. 2012

Presuda Suda Europske unijeGerda Möllendorf $i$ Christiane Möllendorf-Niebuus, C-117/06, ECLI:EU:C:2007:596 , 11. 10. 2007. 
Presuda Suda Europske unije, The Queen, na zabtjev Mi dr. protiv Her Majesty's Treasury, Zabtjev za prethodnu odluku: House of Lords - Ujedinjena Kraljevina, C-340/08, ECLI:EU:C:2010:232, 29. 4. 2010.

Presuda Suda Europske unije, Yassin Adullab Kadi protiv Vijeća Europske unije i Komisije Europskih zajednica, ECLI:EU:T:2005:332, 29. 4. 2010., 21. 9. 2005.

Presuda Suda Europske unije, Yassin Abdullab Kadi i Al Barakaat International Foundation protiv Vijeća Europske unije i Komisije Europskib zajednica, spojeni predmeti C-402/05 P i C-415/05 ECLI:EU:C:2008:461, 3. 9. 2008.,

Presuda Suda Europske unije, Adib Mayaleb protiv Vijeća Europske unije, spojeni predmeti T307/12 i T408/13 ECLI:EU:T:2014:926, 5. 11. 2014.,

Presuda Suda Europske unije, Omar Mohammed Othman protiv Vijeća Europske unije i Komisije Europskih zajednica, T-318/01, ECLI:EU:T:2009:187, 11. 6. 2009.

Presuda Suda Europske unije, Al-Bashir Mohammed Al-Faqib i drugi protiv Vijeća Europske unije, T-135/06 do T-138/06, ECLI:EU:T:2010:412, 29. 9. 2010.,

Presuda Suda Europske unije, Faraj Hassan protiv Vijeća Europske unije i Komisije i Chafiq Ayadi protiv Vijeća, C-399/06 i 403/06, ECLI:EU:C:2009:748,

Presuda Suda Europske unije, Chafiq Ayadi protiv Vijeća EU, T-253/02 ECLI:EU:T:2006:200, 12. 6. 2006.

Presuda Suda Europske unije, Yassin Abdullab Kadi protiv Europske komisije, T-85/09, ECLI:EU:T:2010:418, 30. 9. 2010.,

Presuda Suda Europske unije, Europska komisija idr. protiv Yassin Abdullab Kadi, spojeni predmeti C-584/10 P, C-593/10 P i C-595/10 P, ECLI:EU:C:2013:518, 18.7.2013.,

Presuda Suda Europske unije, People's Mojahedin Organization of Iran protiv Vijeća Europske unije, T-256/07 ECLI:EU:T:2008:461, 23. 10. 2008.

Presuda Suda Europske unije, Liberation Tigers of Tamil Eelam (LTTE) protiv Vijeća Europske unije, spojeni predmeti T-208/11 i T-508/11, ECLI:EU:T:2014:885, 16. 10. 2014.,

Presuda Suda Europske unije, Chafiq Ayadi protiv Europska komisija, C-183/12 P, ECLI:EU:C:2013:369, 6. 6. 2013.

Presuda Suda Europske unije, Abdulbasit Abdulrabim protiv Vijeća Europske unije i Europske komisije, T-127/09 RENV, ECLI:EU:T:2015:4, 14. 1. 2015.,

Presuda Suda Europske unije, Bank Melli Iran protiv Vijeća Europske unije, T-35/10, ECLI:EU:T:2013:397, 6. 9. 2013.,

Presuda Suda Europske unije, Organisation des Modjabedines du people d'Iran protiv Vijeća Europske unije, T-228/02 ECLI:EU:T:2006:384, 12. 12. 2006.,

Presuda Suda Europske unije, Fulmen i Fereydoun Mabmoudian protiv Vijeća Europske unije, T-439/10 i T-440/10, ECLI:EU:T:2012:142, 21. 3. 2012.,

Presuda Suda Europske unije, Stichting Al-Aqsa protiv Vijeća Europske unije, T-327/03, ECLI:EU:T:2007:211, 11. 7. 2007.,

Presuda Suda Europske unije, Jose Maria Sison protiv Vijeća Europske unije, T-341/07, ECLI:EU:T:2011:687, 23. 11. 2011., 
Presudu Suda Europske unije, People's Mojahedin Organization of Iran protiv Vijeća Europske unije, T-284/08 ECLI:EU:T:2008:550, 4. 12. 2008.,

Presuda Suda Europske unije, Stichting Al-Aqsa protiv Vijeća Europske unije, T-348/07, ECLI:EU:T:2010:373, 9. 9. 2010.,

Presuda Suda Europske unije, Jose Maria Sison protiv Vijeća Europske unije, T-47/03 DEP, ECLI:EU:T:2007:207, 11. 7. 2007.,

Presuda Suda Europske unije, Sofiane Fahas protiv Vijeća Europske unije, T-49/07 ECLI:EU:T:2010:499, 7. 12. 2010.

Presuda Suda Europske unije, Vijeće Europske unije protiv Nadiany Bamba C-417/11 ECLI:EU:C:2012:718, 15. 11. 2012.,

Presuda Suda Europske unije, Syrian Lebanese Commercial Bank SAL protiv Vijeća Europske unije T-174/12 i 80/13, ECLI:EU:T:2014:52, 4. 2. 2014.,

Presuda Suda Europske unije, Bank Melli Iran protiv Vijeća Europske unije, T-390/08, ECLI:EU:T:2009:401, 14. 10. 2009.,

Presuda Bank Melli Iran protiv Vijeća Europske unije, C-548/09 P, ECLI:EU:C:2011:735, 16.11.2011.,

Presuda Suda Europske unije, Tarif Akbras protiv Vijeća Europske unije, T-579/11 R ECLI:EU:T:2015:97, 12. 2. 2015.,

Presuda Suda Europske unije, Francuska protiv People's Mojabedin Organization of Iran, C-27/09 P ECLI:EU:C:2011:853, 21. 12. 2011.,

Presuda Suda Europske unije, Kongra-Gel $i$ drugi protiv Vijeća Europske unije, T-253/04, ECLI:EU:T:2008:88, 3. 4. 2008.,

Presuda Suda Europske unije, Manufacturing Support \& Procurement Kala Naft Co., Tehran protiv Vijeća Europske unije, T-509/10, ECLI:EU:T:2012:201, 25. 4. 2012.,

Presuda Suda Europske unije, Vijeće Europske unije protiv Manufacturing Support \& Procurement Kala Naft Co., Tehran, C-348/12 P, ECLI:EU:C:2013:776, 28. 11. 2013.,

Presuda Suda Europske unije Chafiq Ayadi protiv Europske komisije T-527/09 RENV ECLI:EU:T:2015:205, 14. 4. 2015.,

Presuda Suda Europske unije, Issam Anbouba protiv Vijeća Europske unije, T-563/11 ECLI:EU:T:2013:429, 13. 9. 2013.,

Presuda Suda Europske unije, Pye Phyo Tay Za protiv Vijeća Europske unije, C-376/10 P, ECLI:EU:C:2012:138., 13. 3. 2012.,

Presuda Suda Europske unije, H. Jippes, Afdeling Groningen van de Nederlandse Vereniging tot Bescherming van Dieren i Afdeling Assen en omstreken van de Nederlandse Vereniging tot Bescherming van Dieren protiv Minister van Landbouw, Natuurbeheer en Visserij, Zabtjev za prethodnu odluku: College van Beroep voor bet bedriffleven - Nizozemska, C-189/01 ECLI:EU:C:2001:420, 12. 7. 2001.

Presuda Suda Europske unije, The Queen, na zabtjev S.P.C.M. SA, C.H. Erbslöh KG, Lake Chemicals and Minerals Ltd i Hercules Inc. protiv Secretary of State for the Environment, FoSuda Europske unijeand Rural Affairs, Zabtjev za prethodnu odluku: High Court of Justice (England \& Wales), Queen's Bench Division (Ad- 
ministrative Court) - Ujedinjena Kraljevina, C558/07 ECLI:EU:C:2009:430, 7. 7. 2009.,

Presuda Suda Europske unije, Industria Lavorazione Carni Ovine Srl protiv Regione Lazio, Zabtjev za prethodnu odluku: Corte suprema di cassazione - Italija, C534/06 ECLI:EU:C:2008:319, 5. 6. 2008.

Presuda Suda Europske unije, Volker und Markus Schecke GbR (C-92/09) i Hartmut Eifert (C-93/09) protiv Land Hessen, Zabtjevi za prethodnu odluku: Verwaltungsgericht Wiesbaden - Njemačka, C-92/09 i C-93/09 ECLI:EU:C:2010:662, 9. 11. 2010.,

Mišljenje nezavisnog odvjetnika Bota, C584/10 P, C593/10 P and C595/10 P, ECLI:EU:C:2013:176, 19.3.2013.

\section{THE COURT OF EUROPEAN UNION'S SUPERVISION OVER SANCTIONS IMPOSED ON NATURAL AND LEGAL PERSONS}

\section{Summary}

Sanctions or restrictive measures applicable against persons and other entities connected with terrorism, proliferation of nuclear weapons, or repression against civilians necessarily lead to infringement of certain rights of these persons. Financial restrictions primarily refer to financial instruments and financial resources belonging to, owned, beld, or controlled by these persons and restriction of their economic activities. Infringement of procedural rights of such persons (i.e. right to legal aid, right to be beard, including the right of access to court, right to an effective remedy, and right to obtain reasons for imposing sanctions. The Court of the European Union has confirmed its role of protector of persons and entities targeted by sanctions, simultaneously bindering the process of sanctioning. However, there is the issue of undermining the authority of the UN and disturbing the international balance of power. The EU member states are required to uphold the decisions of the Court of the European Union at all times, including in cases when the Court repeals acts introducing the UN sanctions. This could lead to situations where the Court would de facto force the member states to act contrary to Article 103 of the UN Charter. Article 103 explicitly stipulates that obligations arising from the UN Charter have priority before all the other international agreements. This impasse can be solved through quality international cooperation and enbancement of mutual trust based on the respect of both international and European law.

Key words: restrictive measures, sanctions, Court of the European Union, protection of fundamental rights, right of ownership, procedural rights 